\title{
Surfactant Protein B Deficiency Caused by Homozygous C248X Mutation-A Case Report and Review of the Literature
}

\author{
Stefan Kurath-Koller, MD ${ }^{1}$ Bernhard Resch ${ }^{2} \quad$ Raimund Kraschl, MD ${ }^{3} \quad$ Christian Windpassinger ${ }^{4}$ \\ Ernst Eber ${ }^{5}$
}

${ }^{1}$ Division of General Pediatrics, Paediatric Department, Medical University of Graz, Graz, Austria

2 Division of Neonatology, Paediatric Department, Research Unit for Neonatal Infectious Diseases and Epidemiology, Medical University of Graz, Graz, Austria

${ }^{3}$ Division of Neonatology, Pediatric Department, General Hospital of Klagenfurt, Klagenfurt, Austria

${ }^{4}$ Department for human Genetics, Medical University of Graz, Graz, Austria

${ }^{5}$ Division of Pulmonology, Paediatric Department, Medical University of Graz, Graz, Austria

Am J Perinatol Rep 2015;5:e53-e59.

\author{
Address for correspondence Stefan Kurath-Koller, MD, \\ Auenbruggerplatz 34/2, 8036 Graz, Austria \\ (e-mail: stefan.kurath@medunigraz.at).
}

\begin{abstract}
Keywords

- surfactant

- newborn infant

- respiratory distress

- surfactant protein B deficiency

Objective Surfactant protein B (SP-B) deficiency is a rare autosomal recessive disorder that is usually rapidly fatal. The c.397delCinsGAA mutation (121ins 2 ) in exon 4 is found in more than two-thirds of patients.

Design We report on a fatal case of SP-B deficiency caused by a homozygous C248X mutation in exon 7 of the SP-B gene. In addition, we provide an update of the current literature. The EMBASE, MEDLINE, and CINAHL databases were systematically searched to identify all papers published in the English and German literature on SP-B deficiency between 1989 and 2013.

Results SP-B deficiency is characterized by progressive hypoxemic respiratory failure generally in full-term infants. They present with symptoms of respiratory distress and hypoxemia; chest $\mathrm{X}$-ray resembles hyaline membrane disease. Prenatal diagnosis is possible from amniotic fluid or chorionic villi sampling.

Conclusion Thirty-four mutations have been published in the literature. Treatment options are scarce. Gene therapy is hoped to be an option in the future.
\end{abstract}

Surfactant protein B (SP-B) deficiency is a rare disease with an estimated incidence of 1 in 1 million live births. ${ }^{1-3}$ Although the clinical picture initially varies in severity and symptoms, SP-B deficiency constitutes a progressive disorder that commonly presents as severe lung disease requiring mechanical ventilation and even cardiopulmonary bypass. ${ }^{4,5}$ Only transient and inconsistent responses to interventions including exogenous surfactant administration and high-dose corticosteroids have been reported. ${ }^{4}$ Clinical and radiographic findings are consistent with respiratory distress syndrome in preterm born infants. $^{6,7}$ At present, lung transplantation represents the only therapeutic option offering long-term survival. ${ }^{5,8,9}$ We searched the literature between 1989 and 2013 on SP-B deficiency using the EMBASE, MEDLINE, and CINAHL databases to provide data on published mutations and single-nucleotide polymorphisms (SNPs) as well as an overview on current received

August 18, 2014 accepted after revision December 23, 2014

published online

March 2, 2015
DOI http://dx.doi.org/ 10.1055/s-0035-1545668. ISSN 2157-6998.
Copyright (c) 2015 by Thieme Medical Publishers, Inc., 333 Seventh Avenue, New York, NY 10001, USA. Tel: +1(212) 584-4662.
License terms

(요 $\Theta \circledast$ 
knowledge regarding diagnosis and treatment. Further, we report on a case of a fatal SP-B deficient infant.

\section{Case Report}

We report on a male neonate of 40 weeks' gestational age and 3.260-g birth weight, born to a 41-year-old mother. Parents were Caucasian and not related. This was the second pregnancy that proceeded uneventful. Amniocentesis was performed showing a normal male karyotype. The boy was born by caesarean section and initially presented with a weak cry, shallow breathing, hypotonia, and peripheral cyanosis.

Following bag-mask ventilation for 1 minute, the infant's breathing improved and the skin turned rosy. Subsequently, nasal continuous positive airway pressure (CPAP) was initiated resulting in prompt adaptation. Apgar scores were 7/10/10 at 1/ $5 / 10$ minutes, respectively. Body length $(52 \mathrm{~cm})$ and head circumference $(35 \mathrm{~cm})$ were within normal ranges. Within the first hours of life tachy- and dyspnea increased and oxygen demand was increasing $\left(\mathrm{FiO}_{2} 0.3-0.5\right)$, whereas auscultation was unremarkable. At the age of 4 hours the infant was transferred to the neonatal intensive care unit (NICU) presenting with tachypnea (RR 70/min), pale skin, expiratory wheezing, and respiratory distress. $\mathrm{SpO}_{2}$ was $93 \%$ at $\mathrm{FiO}_{2}$ of 0.3 . Chest X-ray showed mild diffuse infiltrations in both lungs ( - Fig. 1). Laboratory findings revealed respiratory acidosis $\left(\mathrm{PaCO}_{2} 56 \mathrm{~mm} \mathrm{Hg}\right)$. On the third day of life, mechanical ventilation was initiated because of worsened respiratory status, $\mathrm{FiO}_{2}$ of 0.7 , and $\mathrm{PaCO}_{2}$ of $68 \mathrm{~mm} \mathrm{Hg}$. Chest X-ray revealed reduced lung volume and reticular infiltrations with positive air bronchogram. Surfactant replacement therapy $(100 \mathrm{mg} / \mathrm{kg}$ body weight porcine surfactant [Curosurf, Chiesi Pharmaceuticals, Vienna, Austria]) resulted in acute improvement of oxygenation (reduction of $\mathrm{FiO}_{2}$ to 0.4 ). However, within the following hours oxygen demand increased again. Within the first week of life $\mathrm{FiO}_{2}$ ranged between 0.5 and 0.7. A 6-day course of methylprednisolone was unsuccessful. Congenital heart disease was excluded by echocardiography.

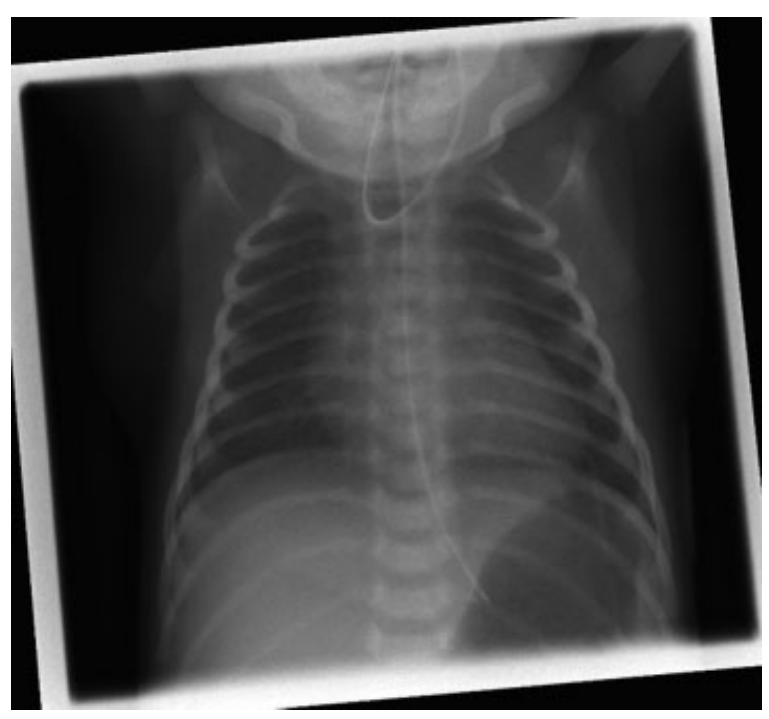

Fig. 1 Early chest X-ray.
High-frequency oscillatory ventilation (HFOV) in combination with inhaled nitric oxide, as well as repeated surfactant supplementation and subsequent conventional mechanical ventilation, resulted in solely intermittent respiratory improvement and oxygen demand persisted at $\mathrm{FiO}_{2}$ of 0.4 to 0.5 . As far as surfactant dysfunction disorder was suspected, SP gene analysis from a blood sample was performed (University Hospital of Karlsruhe, Germany). Genetic analysis revealed SP-B deficiency caused by a homozygous C248X (p.Cys248Term, c.758C > A, TGC > TGA) mutation on exon 7 of the SP-B gene. Tracheotomy was performed at day 50 of life (see - Fig. 2 showing chest X-ray). Lung transplant in case of worsening respiratory situation was declined by the parents. At the age of 92 days the boy died due to respiratory failure.

Parents declined further investigations regarding possible heterozygosity.

\section{Surfactant: Components and Metabolism}

Surfactant proteins (SPs) play an important role in metabolism, structure, and function of surfactant. Surfactant contains the four known surfactant associated proteins: SP-A, SP-B, SP-C, and SP-D, which are synthesized and secreted by alveolar type II cells and are classified into hydrophobic (SP-B and SP-C) and hydrophilic (SP-A and SP-D) proteins. ${ }^{10}$ SPs are well characterized regarding the respective genes, amino acid compositions, and messenger RNA (mRNA) sequences. ${ }^{10,11}$

SP-B is a 79 amino acid protein. There is a single gene on the short arm of chromosome 2(2p12-p11.2) responsible for encoding SP-B. ${ }^{10,12}$ SP-B is a hydrophobic protein comprising $2 \%$ of surfactant composition. It is secreted by type II epithelial cells as a large precursor protein (proSP-B). ProSP-B is split by proteolytic enzymes at the amino- and carboxyl-terminus, resulting in a smaller and extremely hydrophobic peptide. ${ }^{7,13,14}$ SP-B is synthesized in the endoplasmic reticulum. mRNA is translated into a 381 amino acid preproprotein, of which the first 23 amino acids comprise a signal peptide that is co-translationally removed. ${ }^{4}$ SP-B is transported

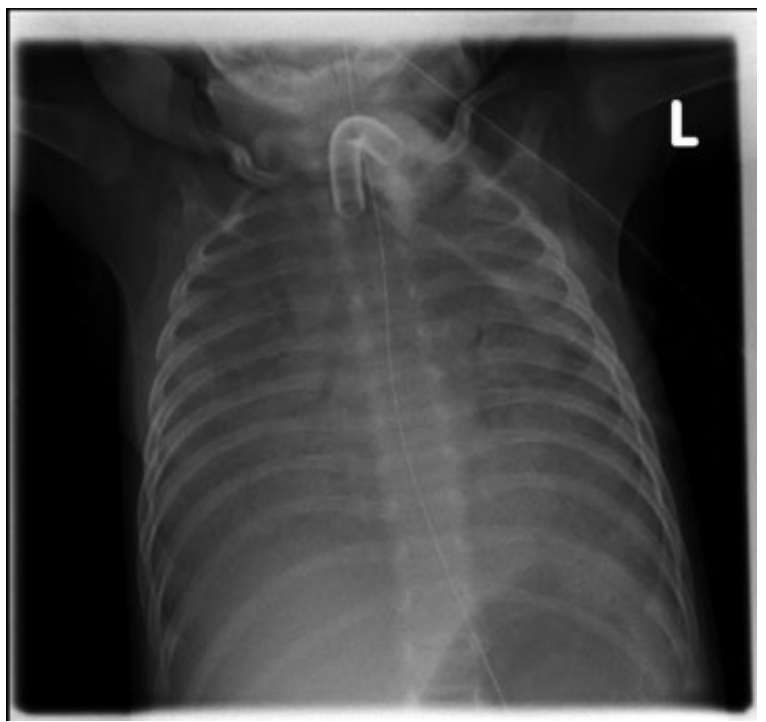

Fig. 2 Chest X-ray after tracheotomy. 
through the Golgi apparatus into multivesicular bodies. During this transport proteolytic processing of the precursor protein is initiated. ${ }^{15}$ The final processing occurs when the multivesicular bodies fuse with the lamellar body. At this stage packaging of the mature protein into surfactant phospholipid membranes takes place. ${ }^{10}$ Being stored in lamellar bodies, SP-B is then secreted into the alveolar lumen by exocytosis. ${ }^{10,16,17}$ Subsequently, the lamellar body converts to produce tubular myelin, which is converted into a lipidrich film spreading along the alveolar surface at the air-liquid interface. ${ }^{10,18,19}$ SP-B enables the adsorption of the surfactant phospholipid film to the air-liquid interface and thereby contributes to the surface tension reducing capacity of surfactant. Furthermore, SP-B participates in the formation of tubular myelin. ${ }^{10,18-21}$ Recycling of surfactant phospholipids and proteins is performed by alveolar type II cells after endocytosis; alternatively, they are catabolized by alveolar macrophages. The expression of SP-B and other proteins involved in surfactant metabolism increases in late gestational age along with other aspects of lung maturation. ${ }^{10}$ During the last third of gestation immature glycogen-rich alveolar type II cells begin to mature, resulting in the disappearance of glycogen while surfactant production increases. ${ }^{22}$

\section{Genetics and Histopathology of SP-B Deficiency}

SP-B deficiency is an autosomal recessive disorder. Carriers of only one mutation are usually asymptomatic. ${ }^{22,23}$ SP-B deficiency was first recognized in 1993 in a family with three full-term infants who died from fatal respiratory disease with clinical and radiologic findings mimicking surfactant deficiency. ${ }^{7}$ Complete lacking of SP-B in lung tissue was found, as well as undetectable levels of mRNA. ${ }^{7}$ Subsequently, affected children were found to be homozygous for a frameshift mutation being responsible for the lack of SP-B, constituting SP-B deficiency as basis of the infant's disease. ${ }^{14}$ The same mutation was also found in three other infants unrelated to those described earlier, who had died from similar lung disease. These findings indicated the mutation found to be relatively common for this disease. The mutation involves the substitution of three bases for one in exon 4 of the gene, corresponding to codon 121 of the SP-B mRNA, and has been termed 121 ins 2 mutation for the net two base-pair insertion. ${ }^{4}$ Current nomenclature for this mutation is c.397delCinsGAA according to DNA level. ${ }^{24}$ This mutation results in extremely low levels of SP-B mRNA, caused by rapid degradation of the mutated mRNA lacking a polyadenylation sequence. - Table 1 shows currently known mutations in the SP-B gene bearing clinical relevance revealed by literature research. ${ }^{3,5,11,19,25-35}$ More than two-thirds of patients carry the c.397delCinsGAA mutation. The residual mutations include nonsense, missense, frameshift, and splice-site mutations, as well as insertions and deletions throughout the gene and a large deletion comprising exons 7 and $8 .^{30,34}$ SP-B is detected in human fetal lung tissue (mRNA) as early as 12 weeks' gestation and in human amniotic fluid from 30 weeks' gestation onward. Mutations of the SP-B gene generally result in loss of function or even complete absence of SP-B, causing acute respiratory distress in full-term infants. Respiratory distress is progressive and usually fatal at 3 to 6 months of age. ${ }^{5}$ Genetic counseling is important due to a recurrence risk of $25 \%$.

From the histopathologic point of view, SP-B deficiency is associated with congenital pulmonary alveolar proteinosis (PAP) and, although less frequently, with infantile desquamative interstitial pneumonitis. ${ }^{10,36}$ These associations are based on the most characteristic histological feature of SP-B deficiency, which is the accumulation of granular, eosinophilic, periodic acid Schiff-positive, lipoproteinaceous material in the alveolar spaces, often containing desquamated alveolar type II cells and foamy alveolar macrophages. ${ }^{10,36}$ Histological findings of PAP in children caused by mutations in the common $\beta$ or $\alpha$ subunit of the granulocyte-macrophage colony-stimulating factor (GM-CSF) receptor differ to those in SP-B deficiency. ${ }^{10,37-39}$ Alveolar proteinosis material is found in large amounts in association with impaired GM-CSF function, whereas alveolar proteinosis material in SP-B deficient infants ranges from large amounts to even complete absence. ${ }^{10}$ Therefore, back in 1998 Nogee suggested that the term hereditary SP-B deficiency more accurately describes the condition than the term congenital alveolar proteinosis. Furthermore, hyperplastic alveolar epithelia with prominent type II cells and thickening of the alveolar walls, characterized by fibroblast proliferation including little to no inflammatory cell infiltrates, distinguishes SP-B deficiency from GM-CSF abnormalities. ${ }^{10}$ Hyperplastic alveolar epithelium interspersed with thickened interstitial septa does not only represent features consistent with impaired alveolar formation, but it may also reflect nonspecific changes in the tissue, eventually being caused by injury from prolonged mechanical ventilation and oxygen therapy. $^{10,40}$

\section{Epidemiology}

The population frequency of SP-B deficiency is currently unknown. However, an incidence of 1 in 1 million live births is estimated for the United States. ${ }^{1}$ The c.397delCinsGAA (121ins2) mutation is represented by an allele frequency of 1 per 1,000 to 3,000 individuals. ${ }^{1-3}$ However, SP-B deficiency constituting a very rare disease might be underdiagnosed due to phenotypic variability and lack of awareness.

\section{Clinical Presentation}

Affected infants present well right after birth, showing no symptoms that might lead to the suspicion of SP-B deficiency. Hours after birth infants develop symptoms of surfactant deficiency, including tachypnea, grunting, retractions, nasal flaring, increased oxygen demand, and gray pallor. Blood gas analysis shows acidosis, hypoxemia, and hypercarbia. Radiographic findings show reticulogranular patterns with positive air bronchogram, increasing lung opacification, and reduced lung volume. ${ }^{6}$

Respiratory failure is associated with the need for mechanical ventilation, HFOV, inhaled nitric oxide, or even extracorporeal membrane oxygenation (ECMO). However, these measures and surfactant replacement therapy result in only transient improvement of the respiratory condition. 
Table 1 Mutations of clinical relevance in the SP-B gene published in the literature $3,5,11,19,25-35$

\begin{tabular}{|c|c|c|c|c|c|c|}
\hline DNA level & Protein & AKA & $\begin{array}{l}\text { Allel frequency, } \\
\text { dbSNP }\end{array}$ & Exon & Type & Reference \\
\hline c.74T $>C$ & p.L25P & T52C, (L13P) & $\mathrm{nl}$ & 1 & Miss & Nogee et $\mathrm{al}^{5}$ \\
\hline c. $153 G>A$ & p.W51* & [G441A], (W39X) & $\mathrm{nl}$ & 2 & Nons & Nogee et $\mathrm{al}^{5}$ \\
\hline c.169delC & & [457delC] & $\mathrm{nl}$ & 2 & Frame & Tredano et $a^{32}$ \\
\hline c. $181 \mathrm{~T}>\mathrm{C}$ & p.C61R & [T469C], (C49R) & $\mathrm{nl}$ & 2 & Miss & Nogee et $\mathrm{al}^{5}$ \\
\hline c.208delG & & [496delG] & $\mathrm{nl}$ & 2 & Frame & Tredano et $\mathrm{al}^{3}$ \\
\hline c. $216 G>A$ & p.W72* & [G504A], (W60X) & $\mathrm{nl}$ & 2 & Nons & Nogee et $\mathrm{al}^{3}$ \\
\hline IVS2 $+4 \mathrm{~A}>\mathrm{G}$ & & $209+4 A>G$ & $\mathrm{nl}$ & 2 & Splice & Nogee et $\mathrm{al}^{5}$ \\
\hline c.304-2delA & & 282-2delA & $\mathrm{nl}$ & & Splice & Nogee et al $^{5}$ \\
\hline c.334T > G & p.C112G & [T1486G], (C100G) & $\mathrm{nl}$ & 4 & Miss & Nogee et $\mathrm{al}^{5}$ \\
\hline c.397delCinsGAA & & 121ins2 & $\mathrm{nl}$ rs35328240 & 4 & Frame & Nogee et $\mathrm{al}^{5}$ \\
\hline c.400delC & & $\begin{array}{l}\text { [1552delC], } \\
122 \text { delC }\end{array}$ & $\mathrm{nl}$ & 4 & Frame & $\begin{array}{l}\text { Somaschini } \\
\text { et } \mathrm{al}^{31}\end{array}$ \\
\hline c.401delT & & [1553delT], 122delT & $\mathrm{nl}$ & 4 & Frame & Lin et $\mathrm{al}^{29}$ \\
\hline \multirow[t]{2}{*}{ c.412delT } & & 379delT & $\mathrm{nl}$ & & & Nogee et $\mathrm{al}^{5}$ \\
\hline & $\begin{array}{l}\text { p. } 1143 T \\
\text { c. } 428 \mathrm{~T}>\mathrm{C}\end{array}$ & {$[\mathrm{T} 1580 \mathrm{C}]$} & $\begin{array}{l}0.5039 \\
\text { rs1130866 }\end{array}$ & 4 & $\begin{array}{l}\text { Miss } \\
\text { DP }\end{array}$ & Tredano et $\mathrm{al}^{33}$ \\
\hline c.436_437dupAA & & [2415-2416insAA] & $\mathrm{nl}$ & 5 & Frame & Williams et $\mathrm{al}^{35}$ \\
\hline c. $439 G>A$ & p.G147S & [G2417A], (G135S) & $\begin{array}{l}0.001849 \\
\text { rs35373464 }\end{array}$ & 5 & Miss & Klein et $\mathrm{al}^{28}$ \\
\hline c.501G > T & & [G2479T] & $\mathrm{nl}$ & 5 & Splice & Dunbar et $\mathrm{al}^{26}$ \\
\hline c.718G >A & & $\begin{array}{l}{[\mathrm{G} 2913 \mathrm{~A}] \text {, IVS6 as }} \\
\mathrm{G}-\mathrm{A}+10\end{array}$ & $\mathrm{nl}$ & 6 & Splice & Nogee et $\mathrm{al}^{5}$ \\
\hline c.739T >C & p.C247R & T717C (C235R) & 0.00001829 & 7 & Miss & Nogee et $\mathrm{al}^{5}$ \\
\hline c. $742 \mathrm{C}>\mathrm{T}$ & p.R248C & [C4380T], (R236C) & $\begin{array}{l}0.00005474 \\
\text { rs137853202 }\end{array}$ & 7 & Miss & Ballard et $\mathrm{al}^{25}$ \\
\hline c.780C > A & p.C260* & $\begin{array}{l}\text { C758A } \\
(C 248 X)\end{array}$ & 0.00004056 & 7 & Nons & Nogee et $a^{5}$ \\
\hline c.790C $>\mathrm{T}$ & p.R264C & C768T (R252C) & $\mathrm{nl}$ & 7 & Miss & Nogee et $\mathrm{al}^{5}$ \\
\hline 4729-4730ins18 & & & & 8 & InFrame ins & Wenger et $\mathrm{al}^{34}$ \\
\hline c.1069_1070insCGC & & 1043ins3 & $\mathrm{nl}$ & 9 & InFrame ins & Nogee et $\mathrm{al}^{5}$ \\
\hline c.1070_1081del12 & & 1048del12 & $\mathrm{nl}$ & 9 & InFrame del & Nogee et $\mathrm{al}^{5}$ \\
\hline $\begin{array}{l}\text { Deletion of } 2958 \text { bp } \\
\text { incl. ex. 7-8 }\end{array}$ & & & $\mathrm{nl}$ & $7-8$ & $\begin{array}{l}\text { Gross } \\
\text { deletion }\end{array}$ & Weaver et $\mathrm{al}^{11}$ \\
\hline $\begin{array}{l}\text { c.673-1248del2959 } \\
\text { incl. ex. 7-8 }\end{array}$ & & & $\mathrm{nl}$ & $7-8$ & $\begin{array}{l}\text { Gross } \\
\text { deletion }\end{array}$ & $\begin{array}{l}\text { Schuerman } \\
\text { et } \mathrm{al}^{30}\end{array}$ \\
\hline 1970insdel(CA)n & & & $\mathrm{nl}$ & Intron 4 & Other & Floros et $\mathrm{al}^{27}$ \\
\hline
\end{tabular}

Abbreviations: AKA, also known as; DP, disease-associated polymorphism; Frame, Frameshift insertion/deletion; InFrame del, In-frame deletion; InFrame ins, In-frame insertion; Miss, Missense, nl, not listed; Nons, nonsense; SP-B, surfactant protein B.

Note: First column DNA level corresponding with HGMD database, NM_198843.2; second column protein referring to XP_005264544.1; fourth column Allel frequency according to Exome Aggregation Consortium (ExAC), Cambridge, MA (URL: http://exac.broadinstitute.org) [12, 2014] and. ${ }^{19}$

In contrast, very few infants appear to have milder respiratory symptoms, with chest X-rays and clinical picture being consistent with more benign diagnoses such as transient tachypnea of the newborn. ${ }^{5}$ Milder disease allowing prolonged survival has been observed in few children with mutations that allow for some residual SP-B production, and has been termed partial SP-B deficiency. ${ }^{26}$ Data of 23 infants with diagnosis of SP-B deficiency from the literature are displayed in - Table 2. ${ }^{7,8,13,28,31,35,41-47}$ Because not all infants reported in the literature are found as full case reports including baseline demographic data and precise clinical course or underlying mutation of the SP-B gene, it is not possible to present all these data in this table for each individual case. 
Table 2 Data on 23 infants with SP-B deficiency reported from the literature $7,8,13,28,31,35,41-47$

\begin{tabular}{|l|l|}
\hline Consanguinity & $7 / 11(64)$ \\
\hline Male gender & $11 / 20(55)$ \\
\hline $\begin{array}{l}\text { Signs of RDS within hours after } \\
\text { birth }\end{array}$ & $23(100)$ \\
\hline Mechanical ventilation & $21 / 23(91)$ \\
\hline Surfactant & $16 / 22(73)$ \\
\hline $\begin{array}{l}\text { Improvement after surfactant } \\
\text { administration }\end{array}$ & $15 / 22(68)$ \\
\hline HFO & $7(30)$ \\
\hline NO & $4(17)$ \\
\hline ECMO & $11(48)$ \\
\hline Corticosteroids & $11(48)$ \\
\hline Survival & $2 / 23(9)$ \\
\hline Death & $21 / 23(91)$ \\
\hline Died at age [d; median (range)] & $62(3-150)$ \\
\hline
\end{tabular}

Abbreviations: ECMO, extracorporeal membrane oxygenation; HFO, high-frequency oxygenation; NO, nitric oxide; RDS, respiratory distress syndrome; SP-B, surfactant protein B.

Note: Data are given as $n(\%)$.

\section{Diagnosis}

Although prenatal diagnosis of SP-B deficiency is possible from 30 weeks' gestation onward using enzyme-linked immunosorbent assay (ELISA) in amniotic fluid ${ }^{41}$ and molecular diagnosis using DNA from either chorionic villi sampling (CVS) or amniotic fluid, it seems important that currently clinical genetic testing constitutes the diagnostic tool broadly available for clinicians ${ }^{48}$. Analyses of amniotic fluid or, postnatally, bronchoalveolar lavage are limited to research laboratories and not available through clinical diagnostic laboratories.

Currently DNA analysis seems to constitute the most reliable diagnostic tool. Surfactant mutation analysis is well established in the United Kindom ${ }^{48}$; however, it remains difficult in many other countries. As stated by Turcu et al, ${ }^{48}$ the rarity of the condition makes it difficult to develop a validated algorithm for genetic testing. International networking might be necessary.

Thin-section chest CT imaging may contribute important information when considering SFTPB deficiency. ${ }^{49}$ Diffuse ground-glass opacity and markedly prominent interlobular septa suggesting alveolar proteinosis might be found. ${ }^{49}$

\section{Treatment}

SP-B deficiency is a fatal disease with lung transplantation remaining the only theoretical treatment option. Maximum supportive therapy including sedation, muscle relaxants, inotropes, high-dose glucocorticoids, and intravenous gamma globulin is often needed. Mechanical ventilation, HFOV, inhaled nitric oxide, and even ECMO may be necessary to improve oxygenation. However, any improvement of oxygenation in classic SP-B deficiency remains temporary with different effects according to phenotypic variations. HFOV combined with neuromuscular blockade often optimizes oxygenation for SP-B deficient infants, and therefore it might be considered while awaiting the diagnosis of SP-B deficiency and bridging to lung transplant. ${ }^{50,51}$ This treatment regimen decreases the synthesis, secretion, or accumulation of dysfunctional surfactant in the alveoli. ${ }^{9}$ Inhaled nitric oxide might be useful in infants who additionally developed pulmonary hypertension. ${ }^{52}$ Recurrent surfactant replacement therapy may or may not result in transient improvement of the respiratory condition, and even up to 80 doses of surfactant have been reported to be ineffective. ${ }^{8}$

Lung transplantation currently represents the only curative option available for SP-B deficient infants. ${ }^{9,50,53-55}$ Short-term outcomes for SP-B deficient infants who underwent lung transplant are comparable to those of infants who were transplanted due to other causes. ${ }^{9,56}$ However, data are based on several 16 infants. In addition, the 5-year survival rate for SP-B deficient infants who received a lung transplant constitutes $50 \%$ and equals the survival rate of infants who underwent lung transplant due to other causes. ${ }^{53,56}$ Short-term mortality is predominantly associated with infection whereas long-term mortality is predominantly due to bronchiolitis obliterans and infections, as well as lymphoproliferative malignancy. ${ }^{53,56}$ However, these results do not appear to be caused by SP-B deficiency but rather by lung transplant itself. ${ }^{53,56}$ Lung transplantation is associated with life-long immunosuppression therapy, lung denervation, and the possibility to develop SP-B antibodies. ${ }^{41,56,57}$ However, SP-B antibody production does not appear to be associated with poorer outcome. ${ }^{56}$ Side effects and risks of life-long immunosuppressive therapy, as well as the need for close and consistent follow-up, the risks of complications, such as graft-versus-host disease, recurrent infections, and hospitalization all must be considered and discussed extensively with the parents. ${ }^{39,57,58}$

\section{Future Aspects}

SP-B deficiency might be an ideal candidate for gene therapy because it constitutes a monogenic defect and is inherited recessively. So far, adenoviral vectors have shown potential to deliver SP-B complementary DNA (cDNA) to animal lungs. ${ }^{59,60}$ Gene therapy might be an approach for future curative therapies, but as compared with gene therapy in cystic fibrosis currently remains target to research.

\section{Conclusion}

Although knowledge on underlying genetic variations constantly increases and genetic testing as well as gene therapy is frequently progressing, SP-B deficiency still remains a very rare and usually fatal disorder primarily affecting term infants. Response to interventions such as exogenous surfactant administration and high-dose corticosteroids are only temporary and infants usually die within the first year of life. If an infant survives bridging to lung transplant-up to now 16 cases have been reported-this reflects the only curative 
treatment option showing 5-year survival rates of 50\%, which are comparable to infants who had undergone lung transplant due to other causes.

\section{References}

1 Cole FS, Hamvas A, Rubinstein P, et al. Population-based estimates of surfactant protein B deficiency. Pediatrics 2000;105(3, Pt 1):538-541

2 Hamvas A, Trusgnich $M$, Brice $H$, et al. Population-based screening for rare mutations: high-throughput DNA extraction and molecular amplification from Guthrie cards. Pediatr Res 2001;50(5):666-668

3 Tredano M, Griese M, de Blic J, et al. Analysis of 40 sporadic or familial neonatal and pediatric cases with severe unexplained respiratory distress: relationship to SFTPB. Am J Med Genet A 2003;119A(3):324-339

4 Nogee LM. Alterations in SP-B and SP-C expression in neonatal lung disease. Annu Rev Physiol 2004;66:601-623 [Review]

5 Nogee LM, Wert SE, Proffit SA, Hull WM, Whitsett JA. Allelic heterogeneity in hereditary surfactant protein B (SP-B) deficiency. Am J Respir Crit Care Med 2000;161(3, Pt 1):973-981

6 Herman TE, Nogee LM, McAlister WH, Dehner LP. Surfactant protein B deficiency: radiographic manifestations. Pediatr Radiol 1993;23(5):373-375

7 Nogee LM, de Mello DE, Dehner LP, Colten HR. Brief report: deficiency of pulmonary surfactant protein $B$ in congenital alveolar proteinosis. N Engl J Med 1993;328(6):406-410

8 Hamvas A, Cole FS, deMello DE, et al. Surfactant protein B deficiency: antenatal diagnosis and prospective treatment with surfactant replacement. J Pediatr 1994;125(3):356-361

9 Hamvas A, Nogee LM, Mallory GB Jr, et al. Lung transplantation for treatment of infants with surfactant protein B deficiency. J Pediatr 1997;130(2):231-239

10 Wert SE, Whitsett JA, Nogee LM. Genetic disorders of surfactant dysfunction. Pediatr Dev Pathol 2009;12(4):253-274 [Review]

11 Weaver TE, Whitsett JA. Function and regulation of expression of pulmonary surfactant-associated proteins. Biochem J 1991;273 (Pt 2):249-264

12 Pilot-Matias TJ, Kister SE, Fox JL, Kropp K, Glasser SW, Whitsett JA. Structure and organization of the gene encoding human pulmonary surfactant proteolipid SP-B. DNA 1989;8(2):75-86

13 deMello DE, Nogee LM, Heyman S, et al. Molecular and phenotypic variability in the congenital alveolar proteinosis syndrome associated with inherited surfactant protein B deficiency. J Pediatr 1994;125(1):43-50

14 Nogee LM, Garnier G, Dietz HC, et al. A mutation in the surfactant protein $\mathrm{B}$ gene responsible for fatal neonatal respiratory disease in multiple kindreds. J Clin Invest 1994;93(4):1860-1863

15 Voorhout WF, Veenendaal T, Haagsman HP, et al. Intracellular processing of pulmonary surfactant protein B in an endosomal/ lysosomal compartment. Am J Physiol 1992;263(4, Pt 1):L479-L486

16 Andreeva AV, Kutuzov MA, Voyno-Yasenetskaya TA. Regulation of surfactant secretion in alveolar type II cells. Am J Physiol Lung Cell Mol Physiol 2007;293(2):L259-L271 [Review]

17 Ryan US, Ryan JW, Smith DS. Alveolar type II cells: studies on the mode of release of lamellar bodies. Tissue Cell 1975;7(3):587-599

18 Pérez-Gil J. Structure of pulmonary surfactant membranes and films: the role of proteins and lipid-protein interactions. Biochim Biophys Acta 2008;1778(7-8):1676-1695

19 Serrano AG, Pérez-Gil J. Protein-lipid interactions and surface activity in the pulmonary surfactant system. Chem Phys Lipids 2006;141(1-2):105-118

20 Yamano G, Funahashi H, Kawanami O, et al. ABCA3 is a lamellar body membrane protein in human lung alveolar type II cells. FEBS Lett 2001;508(2):221-225

21 Weaver TE, Conkright JJ. Function of surfactant proteins B and C. Annu Rev Physiol 2001;63:555-578 [Review]
22 Ridsdale R, Post M. Surfactant lipid synthesis and lamellar body formation in glycogen-laden type II cells. Am J Physiol Lung Cell Mol Physiol 2004;287(4):L743-L751

23 Yusen RD, Cohen AH, Hamvas A. Normal lung function in subjects heterozygous for surfactant protein-B deficiency. Am J Respir Crit Care Med 1999;159(2):411-414

24 Stenson PD, Ball EV, Mort M, et al. Human Gene Mutation Database (HGMD): 2003 update. Hum Mutat 2003;21(6):577-581

25 Ballard PL, Nogee LM, Beers MF, et al. Partial deficiency of surfactant protein B in an infant with chronic lung disease. Pediatrics 1995;96(6):1046-1052

26 Dunbar AE III, Wert SE, Ikegami M, et al. Prolonged survival in hereditary surfactant protein B (SP-B) deficiency associated with a novel splicing mutation. Pediatr Res 2000;48(3):275-282

27 Floros J, Veletza SV, Kotikalapudi P, et al. Dinucleotide repeats in the human surfactant protein-B gene and respiratory-distress syndrome. Biochem J 1995;305(Pt 2):583-590

28 Klein JM, Thompson MW, Snyder JM, et al. Transient surfactant protein B deficiency in a term infant with severe respiratory failure. J Pediatr 1998;132(2):244-248

29 Lin Z, deMello DE, Wallot M, Floros J. An SP-B gene mutation responsible for SP-B deficiency in fatal congenital alveolar proteinosis: evidence for a mutation hotspot in exon 4. Mol Genet Metab 1998;64(1):25-35

30 Schuerman FA, Griese M, Gille JP, Brasch F, Noorduyn LA, van Kaam AH. Surfactant protein B deficiency caused by a novel mutation involving multiple exons of the SP-B gene. Eur J Med Res 2008; 13(6):281-286

31 Somaschini M, Wert S, Mangili G, Colombo A, Nogee L. Hereditary surfactant protein B deficiency resulting from a novel mutation. Intensive Care Med 2000;26(1):97-100

32 Tredano M, Cooper DN, Stuhrmann M, et al. Origin of the prevalent SFTPB indel g.1549C > GAA (121ins2) mutation causing surfactant protein B (SP-B) deficiency. Am J Med Genet A 2006;140(1): 62-69

33 Tredano M, van Elburg RM, Kaspers AG, et al. Compound SFTPB 1549C->GAA (121ins2) and 457delC heterozygosity in severe congenital lung disease and surfactant protein B (SP-B) deficiency. Hum Mutat 1999;14(6):502-509

34 Wegner DJ, Hertzberg T, Heins HB, et al. A major deletion in the surfactant protein-B gene causing lethal respiratory distress. Acta Paediatr 2007;96(4):516-520

35 Williams GD, Christodoulou J, Stack J, et al. Surfactant protein B deficiency: clinical, histological and molecular evaluation. J Paediatr Child Health 1999;35(2):214-220

36 Beers MF, Hamvas A, Moxley MA, et al. Pulmonary surfactant metabolism in infants lacking surfactant protein B. Am J Respir Cell Mol Biol 2000;22(3):380-391

37 Dirksen U, Nishinakamura R, Groneck P, et al. Human pulmonary alveolar proteinosis associated with a defect in GM-CSF/IL-3/IL-5 receptor common beta chain expression. J Clin Invest 1997;100(9): 2211-2217

38 Martinez-Moczygemba M, Doan ML, Elidemir O, et al. Pulmonary alveolar proteinosis caused by deletion of the GM-CSFRalpha gene in the X chromosome pseudoautosomal region 1. J Exp Med 2008; 205(12):2711-2716

39 Suzuki T, Sakagami T, Rubin BK, et al. Familial pulmonary alveolar proteinosis caused by mutations in CSF2RA. J Exp Med 2008; 205(12):2703-2710

40 Clark JC, Wert SE, Bachurski CJ, et al. Targeted disruption of the surfactant protein B gene disrupts surfactant homeostasis, causing respiratory failure in newborn mice. Proc Natl Acad Sci U S A 1995; 92(17):7794-7798

41 Andersen C, Ramsay JA, Nogee LM, et al. Recurrent familial neonatal deaths: hereditary surfactant protein B deficiency. Am J Perinatol 2000;17(4):219-224

42 Ball R, Chetcuti PA, Beverley D. Fatal familial surfactant protein B deficiency. Arch Dis Child Fetal Neonatal Ed 1995;73(1):F53 
43 Ferzli G, Yunis KA, Mroueh S. Surfactant protein B deficiency: a rare cause of respiratory failure in a Lebanese newborn. Ann Saudi Med 2006;26(1):69-70

44 Grasemann H, de Perrot M, Bendiak GN, et al. ABO-incompatible lung transplantation in an infant. Am J Transplant 2012;12(3): 779-781

45 Herting E, Schiffmann H, Roth C, Johansson J. Surfactant lavage demonstrates protein fibrils in a neonate with congenital surfactant protein b deficiency. Am J Respir Crit Care Med 2002;166(9): 1292-1294

46 Sleight E, Coombs RC, Gibson AT, Primhak RA. Neonatal respiratory distress in near-term infants-consider surfactant protein B deficiency. Acta Paediatr 1997;86(4):428-430

47 Wallot M, Wagenvoort C, deMello D, Müller KM, Floros J, Roll C. Congenital alveolar proteinosis caused by a novel mutation of the surfactant protein B gene and misalignment of lung vessels in consanguineous kindred infants. Eur J Pediatr 1999;158(6):513-518

48 Turcu S, Ashton E, Jenkins L, Gupta A, Mok Q. Genetic testing in children with surfactant dysfunction. Arch Dis Child 2013;98(7): 490-495

49 Newman B, Kuhn JP, Kramer SS, Carcillo JA. Congenital surfactant protein B deficiency-emphasis on imaging. Pediatr Radiol 2001; 31(5):327-331

50 King EL, Shackelford GD, Hamvas A. High-frequency oscillation and paralysis stabilize surfactant protein-B-deficient infants. J Perinatol 2001;21(7):421-425

51 King E, Shackelford G, Hamvas A. High frequency oscillation with neuromuscular blockade promotes gas exchange in SP-B deficient infants. Am J Respir Crit Care Med 1997;155:A236
52 Hamvas A. Inherited surfactant protein-B deficiency and surfactant protein- $C$ associated disease: clinical features and evaluation. Semin Perinatol 2006;30(6):316-326

53 Hamvas A. Evaluation and management of inherited disorders of surfactant metabolism. Chin Med J (Engl) 2010;123(20): 2943-2947

54 MacLaughlin EF, Woo MS, Horn MV. Lung function changes following infant lung transplantation. Am J Respir Crit Care Med 1996;153:A657

55 Sweet SC, Spray TL, Huddleston CB, et al. Pediatric lung transplantation at St. Louis Children's Hospital, 1990-1995. Am J Respir Crit Care Med 1997;155(3):1027-1035

56 Palomar LM, Nogee LM, Sweet SC, Huddleston CB, Cole FS, Hamvas A. Long-term outcomes after infant lung transplantation for surfactant protein B deficiency related to other causes of respiratory failure. J Pediatr 2006;149(4):548-553

57 Hamvas A. Surfactant protein B deficiency: insights into inherited disorders of lung cell metabolism. Curr Probl Pediatr 1997;27(9): 325-345

58 Spray TL, Mallory GB, Canter CB, Huddleston CB. Pediatric lung transplantation. Indications, techniques, and early results. J Thorac Cardiovasc Surg 1994;107(4):990-999, discussion 999-1000

59 Aneja MK, Rudolph C. Gene therapy of surfactant protein B deficiency. Curr Opin Mol Ther 2006;8(5):432-438

60 Korst RJ, Bewig B, Crystal RG. In vitro and in vivo transfer and expression of human surfactant SP-A- and SP-B-associated protein cDNAs mediated by replication-deficient, recombinant adenoviral vectors. Hum Gene Ther 1995;6(3):277-287 